\title{
Stem Population and Tissue Replacement of Urochloa in Different Phenological Stages
}

\author{
María de los Ángeles Maldonado Peralta1, Adelaido Rafael Rojas García1*, \\ Jessica Lizbeth Ruíz Clavel ${ }^{2}$, Herminio Aniano Aguirre², Filiberto Magadan Olmedo', \\ Leopoldo Jorge Castañeda², Uriel Mondragón Calderón²

\footnotetext{
${ }^{1}$ Universidad Autónoma de Guerrero, Facultad de Medicina Veterinaria y Zootecnia, Cuajinicuilapa, Guerrero, México

${ }^{2}$ Tecnológico Nacional de México, Campus Instituto Tecnológico de Pinotepa, Pinotepa Nacional, Oaxaca, México

Email: *rogarcia@uagro.mx
}

How to cite this paper: Maldonado Peralta, M.Á., Rojas García, A.R., Ruíz Clavel, J.L., Aniano Aguirre, H., Magadan Olmedo, F., Jorge Castañeda, L. and Mondragón Calderón, U. (2020) Stem Population and Tissue Replacement of Urochloa in Different Phenological Stages. American Journal of Plant Sciences, 11, 1296-1306. https://doi.org/10.4236/ajps.2020.118092

Received: July 9, 2020

Accepted: August 18, 2020

Published: August 21, 2020

Copyright $\odot 2020$ by author(s) and Scientific Research Publishing Inc. This work is licensed under the Creative Commons Attribution International License (CC BY 4.0).

http://creativecommons.org/licenses/by/4.0/

\begin{abstract}
The objective of the present investigation was to evaluate the Urochloa Insurgent, Piata and Signal grasses by varying the phenology in the attributes: stem population dynamics, tissue replacement, leaf:stem relation and weight per stem. The data were analyzed using a completely randomized block design with arrangement in divided plots and four replications, the procedure used was PROC GLM from SAS. The Signal grass presented higher stem density with an average of $450 \mathrm{~m}^{-2}$ stems, while the meadow with Insurgent grass registered the lowest stem density throughout the investigation, with an average of $320 \mathrm{~m}^{-2}$ stems; furthermore, in this treatment, the stem density tended to increase slowly over time $(\mathrm{P}=0.05)$. The Insurgente and signal grasses showed rapid leaf elongation from day 21 of regrowth with 123 and $104 \mathrm{~cm} \mathrm{stem}^{-1}$, while in Piata the accelerated leaf elongation was on day 14 with $113 \mathrm{~cm} \mathrm{stem}^{-1}$ where it remained active its growth until day $56(\mathrm{P}>$ $0.05)$. As the regrowth age was increasing, the population dynamics of stems and weight per stem were increasing; in Insurgent and signal the leaf elongation and net growth increased to a maximum point to start declining; however, in Piata grass was increasing without decreasing. The trend of the leaf:stem relation was decreasing as the test progressed and senescence increased from day 21 of regrowth.
\end{abstract}

\section{Keywords}

Urochloa, Stem Population, Leaf Elongation, Weight Per Stem

\section{Introduction}

Cattle feed on native forage, stubble, grain, and sometimes supplemented with 
legume pods in the tropics [1] [2]. Nutrition represents between $50 \%$ and $80 \%$ of production costs, the pastures used are wild or semi-cultivated, adapted to extreme edapho-climatic conditions, used for the genetic improvement of new varieties or genotypes [3] [4] that will be implemented in future agricultural challenges [5] [6]; even so, there is ignorance in the description of the morphological characteristics, crosses, distribution and genetic improvement [7].

In most ruminant producing tropical areas, they suffer nutritional stress either temporarily or permanently [8]. The hybrid forages of Brachiaria now Urochloa are originated from Africa and are considered an alternative that meets basic nutritional requirements, providing better quality dry matter [9] [10], compared to native forages, mainly for the dry season.

Studies indicate that these species have been used for in vivo investigations in cattle [11] with positive results; however, management is essential in the persistence of the meadow, which determines the intensity and frequency of cutting or grazing [12], components that modify the animal load, according to the degree of defoliation [13] [14]. Other researchers [15], evaluated different frequencies in Mulato grass (Brachiaria hybrid 36061) and mention that in the rainy season at 21 and 28 days the highest forage production, growth rate and leaf production were obtained. In Cobra grass (Brachiaria HYBRID BR02/1794), the growth curve was evaluated, determining that 35 days after regrowth it has higher quality and quantity of leaf [16].

Knowledge of the density, weight of the stems and elongation of leaves provides an essential reference for the management of meadow [17]. There are studies where B. brizantha cv, Marandu, B. decumbens and B. ruziziensis have been evaluated; however, it is necessary to investigate the Piata, Signal and Insurgent cultivars, from the basics such as yield, growth dynamics and quality, cultivated alone and in associations [18] [19]. Therefore, the objective of the present investigation was to evaluate the Urochloa Insurgent, Piata and Signal grasses by varying the phenology in the attributes: stem population dynamics, tissue replacement, leaf:stem relation and weight per stem.

\section{Materials and Methods}

\subsection{Location of the Experimental Area}

The present investigation was carried out in the experimental unit of the Instituto Tecnológico de Pinotepa, located at kilometer 26 of the Pinotepa Nacional highway, Oaxaca-Acapulco, south of the town of San José Estancia Grande, Oaxaca, in the period from August to December from 2017 and laboratory analyzes in the same experimental unit from January to June 2018.

It is located at $16^{\circ} 22^{\prime}$ north latitude and $98^{\circ} 13^{\prime}$ west longitude, with a height of 60 masl according to the Köeppen climate classification, it presents an Aw (w) ig climate, it corresponds to a sub-humid warm climate [20], with a rainy season in summer. The pluvial precipitation is in a range of $1000-1500 \mathrm{~mm}$ annually with a rainy period that includes from June to September with 8 months of drought, 
with an average temperature of $26^{\circ} \mathrm{C}-28^{\circ} \mathrm{C}$.

\subsection{Plots Management}

The sowing was carried out on August 10,2017, with pure viable seed from three grasses of the Urochloa genus. The sowing method was direct, at a distance between furrow and furrow of $50 \mathrm{~cm}$ and between plants of $20 \mathrm{~cm}$. Four $10 \times 5 \mathrm{~m}$ plots were sowed, being experimental units for each grass. These are in turn in eight areas, in order to evaluate a growth analysis with eight regrowth ages. The soil with a sandy clay texture, $\mathrm{pH} 4.8$ to 5.0 , deficient in organic matter. The weed was controlled manually with the help of a hoe, two nitrogen fertilizations were carried out with urea (46-00-00), the first was done on September 28 and the second was on October 17, 2017. On October 12, 2017, a homogenization cut was made at a height of $10 \mathrm{~cm}$ in all the experimental plots. Irrigation was carried out every 3 days by the drip method from the date of the cut until completed the investigation.

\subsection{Stem Population Dynamics}

To determine the changes in the density of stems, at the beginning of the experiment, two PVC rings of $10.4 \mathrm{~cm}$ diameter were placed in each experimental unit, which delimited a tiller. All the stems present inside the ring were marked with cable rings of the same color, which were considered as the initial population. Subsequently, each week for eight weeks, the new stems were marked with different colored rings; a different color was used for each generation, and the dead stems were counted and the ring was removed.

\subsection{Tissue Replacement}

Total growth, net growth and foliar senescence were evaluated in a $2 \mathrm{~m}$ long transept, five stems of each grass were randomly selected and identified with wire rings of different color. Stems measured: the length of the foliar blade, from the base of the ligule to the apex in green leaves or to the base of the chlorotic tissue in senescent leaves. A linear regression equation was obtained considering the foliar area as the dependent variable and the rib length as the independent variable [21].

\subsection{Leaf:Stem Relation}

The leaf:stem relation data was obtained by cutting two $50 \times 50 \mathrm{~cm}$ squares weekly in each experimental plot, leaving $10 \mathrm{~cm}$ of remaining foliar area; separating into leaf and stem, and it was deposited in a forced air stove at $55^{\circ} \mathrm{C}$ until constant weight, recording the weight to estimate the dry matter per hectare, at the different phenologies, dividing the leaf between the stem.

\subsection{Weight Per Stem}

The weight per stem was recorded one day before weekly cutting, 10 stems of 
each grass were cut at ground level, dried in a forced air stove at $55^{\circ} \mathrm{C}$ until constant weight and their weight was recorded. The average weight per stem was obtained by dividing the total weight by the number of stems harvested.

\subsection{Statistic Analysis}

The data were analyzed using a completely randomized block design with arrangement in divided plots and four replications, the procedure used was PROC GLM [22], where the cutting frequency effects were considered as fixed. The multiple comparison of means of the treatments was performed using the Tukey test $(\alpha=0.05)$.

\section{Results and Discussion}

\subsection{Dynamics of Stems Population}

Figures 1(a)-(c) show the stem density throughout the experimental period in the three grasses of the genus Urochloa. From day 49 to 56, the highest stem density was recorded, independently of the grass $(P=0.05)$. Signal grass (Figure 1(c)) had the highest stem density with an average of $450 \mathrm{~m}^{-2}$ stems, while the Insurgent grass meadow (Figure 1(a)) registered the lowest stems density throughout the investigation, with an average $320 \mathrm{~m}^{-2}$ stems; furthermore, in this treatment, the stem density tended to increase slower over time; with a multiple average of $376 \mathrm{~m}^{-2}$ stems.

On average, all the grasses presented lower stem density at the beginning of the growth curve (day 7), and it can be attributed to the beginning of the growth curve since at the beginning of the regrowth the tillers tend to have a lower population of stems and the largest foliar area and, therefore, the higher the weight with time to establish the meadow [23]. Another factor that affected this behavior of stems was the inter-specific competition for nutrients, water, light and space [24], since the plants do not regrowth in a meadow as isolated individuals, but as a usually dense population, where the vegetation that It surrounds them exerts a very strong influence on the inherent characteristics of each species, through competition [17].

Other authors, [25] in the dry tropics in the population density of stem, obtained similar results to this study when evaluating regrowth patterns of Elephant grass (Pennisetum purpureum) subjected to two pre-grazing heights (90 and $120 \mathrm{~cm}$ ), where they observed $293 \mathrm{~m}^{-2}$ stems in the initial regrowth state, followed by a significant increase and the highest values in the intermediate state (420 $\mathrm{m}^{-2}$ stems) and a decrease in the final state $\left(331 \mathrm{~m}^{-2}\right.$ stems); on the other hand, when evaluating the Llanero grass (Andropogon gayanus Kunt) they reported an average of 350 stems $\mathrm{m}^{-2}$ in a growth curve, results similar to those of this test [26]. On the other hand, [27] when evaluating the Cuba 22 grass in the tropics of Mexico, it obtained a smaller population than that of this study with an average of 76 stems $\mathrm{m}^{-2}$; being highly variable and depends on various factors such as type of grass, climate and management given on the plot. 


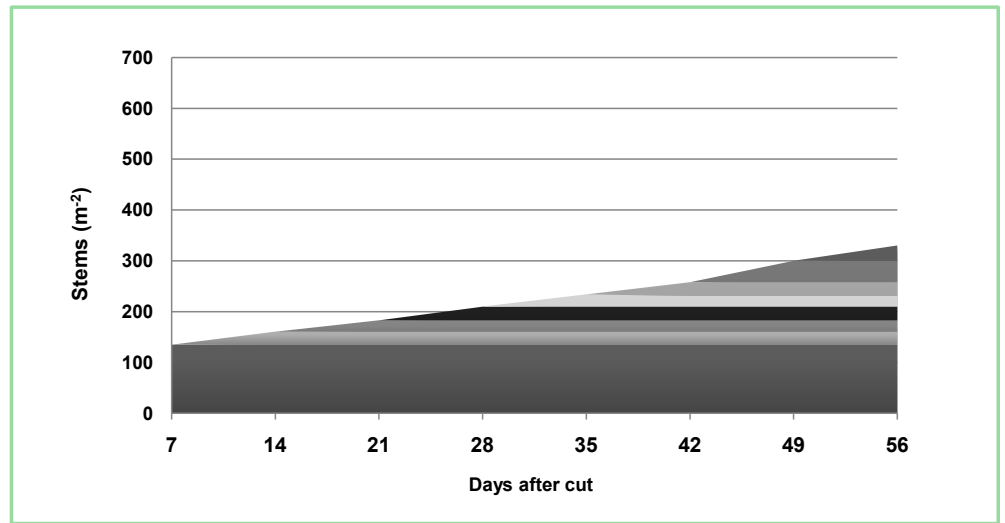

(a)

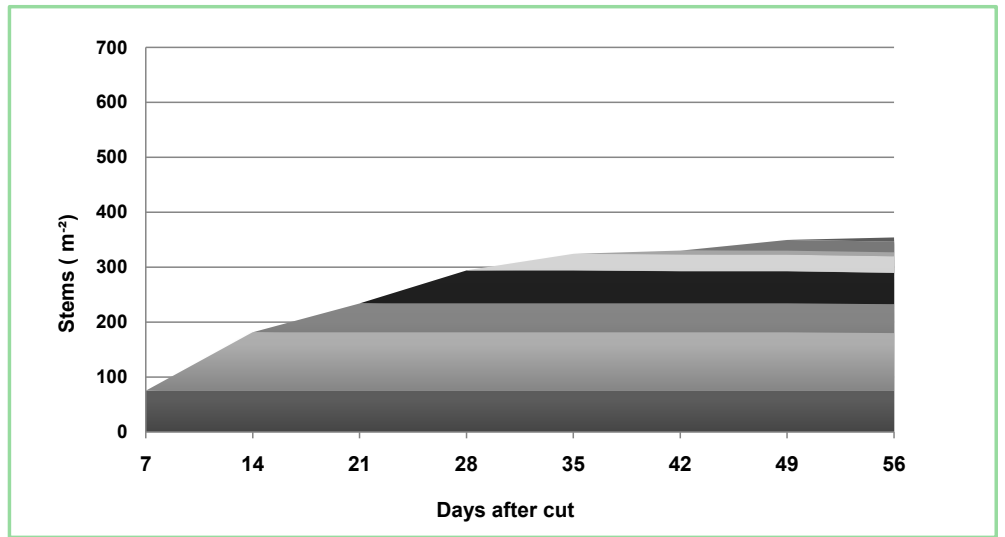

(b)

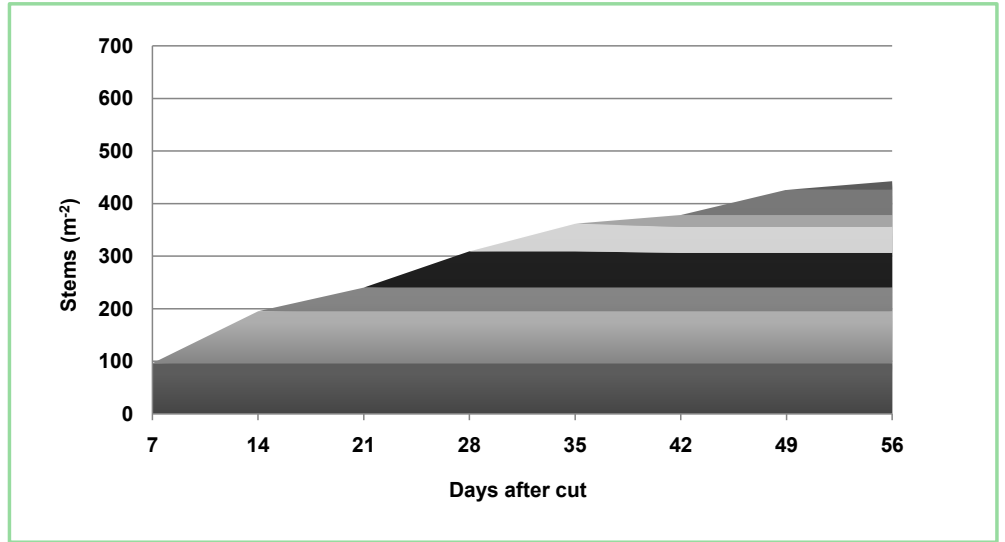

(c)

Figure 1. Population dynamics of grass stems, by varying the cutting frequency. (a) Insurgent Grass (Urochloa brizantha); (b) Piata grass (Urochloa vs Piata); (c) Signal Grass (Urochloa decumbens).

\subsection{Tissue Replacement}

Figures 2(a)-(c) show the leaf elongation, net growth and senescence per stem of three Urochloa grasses (Insurgent, Piata and Signal) by varying the phenological state. The leaf elongation (accumulated growth) the grass that obtained the highest contribution was Piata followed by Insurgent and at the end Signal with 
an average of 140, 134 and $115 \mathrm{~cm} \mathrm{stem}^{-1}$ respectively, and multiple average of $130 \mathrm{~cm} \mathrm{stems}^{-1}(\mathrm{P} \leq 0.05)$. The Insurgent and Signal grasses showed a rapid leaf elongation from day 21 of regrowth with 123 and $104 \mathrm{~cm} \mathrm{stem}^{-1}$, while in Piata the accelerated leaf elongation was on day 14 with $113 \mathrm{~cm} \mathrm{stem}^{-1}$ where it remained active its growth until day $56(\mathrm{P}>0.05)$. Similar behavior was obtained the net growth reporting the highest net growth by Piata grass with $134 \mathrm{~cm}$ $\mathrm{stem}^{-1}$ and the lowest Signal with $108 \mathrm{~cm} \mathrm{stem}^{-1}(\mathrm{P}>0.05)$. The Insurgent and Signal grass the net growth was increasing as the phenology stage passed until reaching the maximum point on day 49 and then descending on day 56; however, in Piata grass, it increased without decreasing $(P>0.05$; Figure 2(b)). Regarding the growth of senescence in the Insurgent grass, it was reported from day 21 with $3.7 \mathrm{~cm} \mathrm{stem}^{-1}$ increasing considerably until reaching on day 56 the maximum senescence with $21.8 \mathrm{~cm} \mathrm{stem}^{-1}$ obtaining the highest amount of senescence per stem $(P>0.05)$. With regard to Signal and Piata grass, senescence began from day 28 of regrowth, remaining constant until day 56.

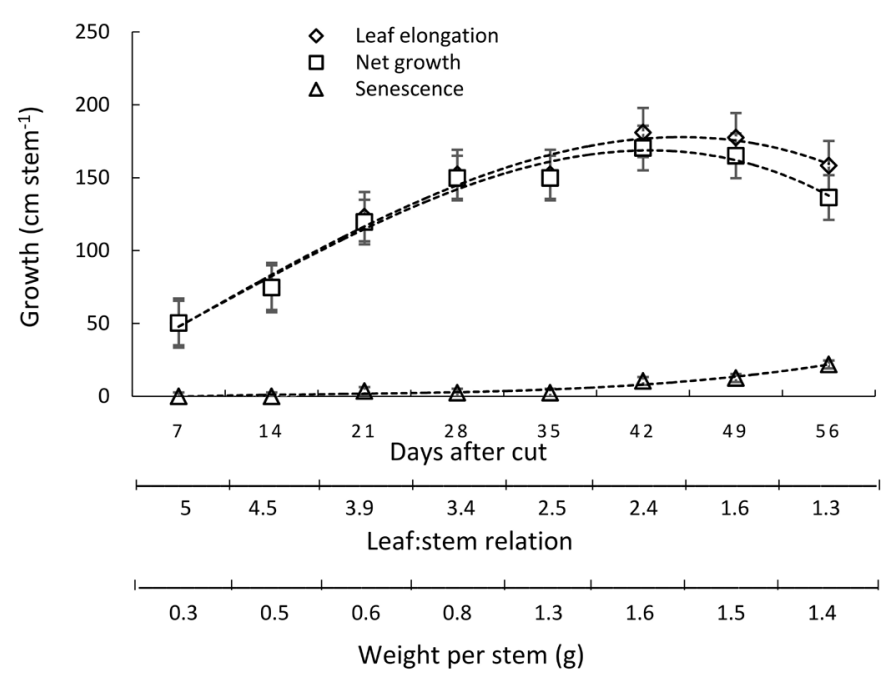

(a)

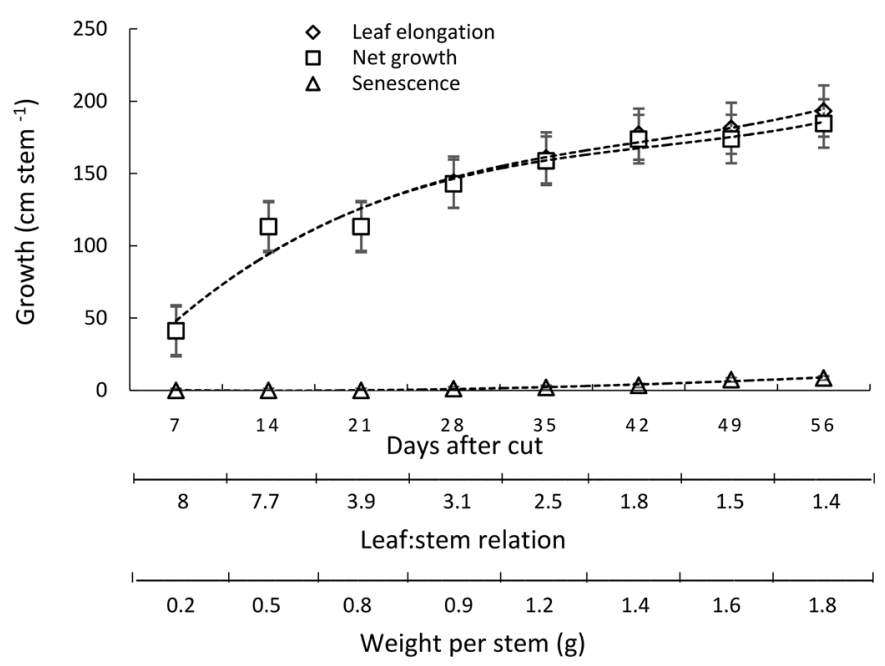

(b) 


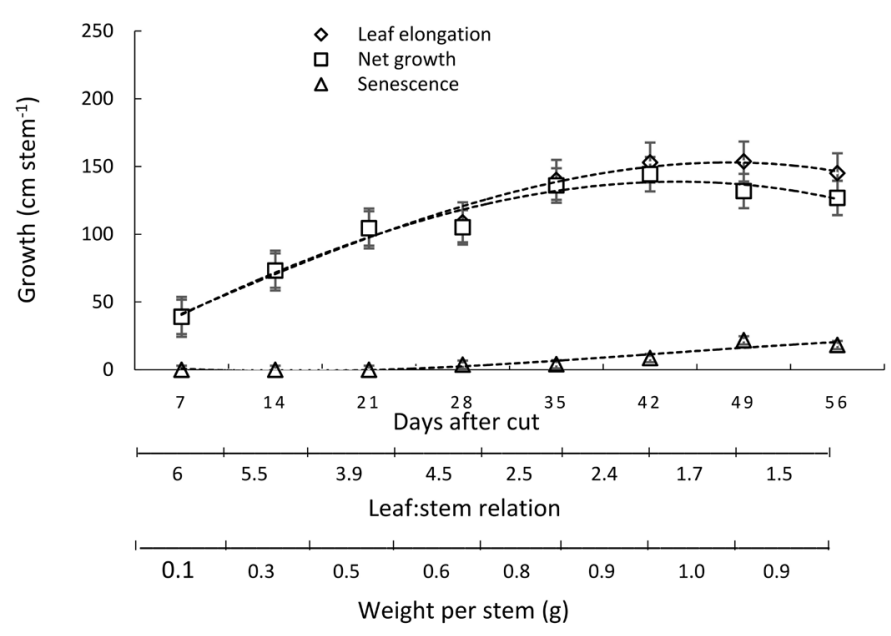

(c)

Figure 2. Tissue replacement, leaf:stem ralation and weight per stem in growth curves. (a) Insurgent Grass (Urochloa brizantha); (b) Piata grass (Urochloa vs Piata); (c) Signal Grass (Urochloa decumbens).

Several authors [21] [28] mention that at the end of the forage accumulation curve senescence losses increase and, therefore, the net forage accumulation decreases as in this investigation. In Cobra grass (Urochloa hybrid) and Cuba 22 (Pennisetum purpureum $x$ Pennisetum glaucum) the maximum leaf growth occurs in the seventh; then growth rates decrease due to a progressive increase in stems and senescent material [16] [27]. The highest growth and trend of these Urochloa grasses is related to a promotion of division and lengthening cell, known effects of cytokinins on cotyledons and leaves of mustard (Brassica nigra) cucurbits (Cucurbita pepo) and sunflower (Helianthus annuus) [29]. After defoliation, the speed with which a forage recovers depends on the reserve carbohydrates in roots, remaining leaf area and the number of vegetative buds started, which increases the photosynthetic capacity of the leaves; and higher elongation and net foliar growth [13].

\subsection{Leaf:Stem Relation}

Figures 2(a)-(c) show the leaf:stem relation of the Insurgent, Piata and Signal grasses by varying phenological states. The leaf:stem relation is a measure of the quality of the meadow since if it is higher than 1 it means that the leaf exceeds the quantity of stem in the meadow. Independently of the grass, the leaf:stem relation decreased as the evaluation period passed $(\mathrm{P}=0.05)$. The highest leaf:stem relation was reported in Piata, Signal and Insurgent grass, 7 days after regrowth with values of 8,6 and 5, respectively $(P=0.05)$. Staying Insurgent and Signal until day 42 of regrowth a leaf:stem relation of 2.4 and lower Piata on that same day $1.8(\mathrm{P}>0.05)$; decreasing until day 56 with an average leaf:stem relation of 1.4. In addition, tillering growth habit and semi-erect growth of the Urochloa grasses, the high leaf:stem relations and the minimal growth of senescence can be explained, because it is concentrated in the lower strata of the meadow that in 
this case is left $10 \mathrm{~cm}$ of remaining foliar area. On the other hand, this behavior of decreasing the leaf:stem relation as the evaluation time increases is closely related to the decrease in net growth and increase in senescence as shown in Figure 2 .

Similar results were obtained by other researchers [27] obtaining a higher leaf:stem relation in early phenologies and decreasing as the time and senescence of the plant increased, obtaining on day 30 a leaf:stem ratio of 2.4 and on day 110 of regrowth 0.8. In Mombaza grass (Panicum maximum Jacq.), when evaluating different cutting frequencies in the rainy and dry season, reported a decrease in leaf:stem ratio in dry (80\%) compared to the rain; in addition, when the frequency increases, the leaf:stem relation decreases on average on day 21, 8.4 decreasing on day 49 with 3.8 of leaf:stem relation, trend and results similar to those of this study [30]. Other researchers [15] in mulatto I (Brahiaria hybrid) now Urochloa report similar results to those of this investigation, they mention that the high values of leaf:stem relation were associated with the management given in the meadow, mainly leaving remaining foliar area, which prevented a large amount of stem from being harvested, which is located close to the soil surface.

\subsection{Weight per Stem}

Figures 2(a)-(c) show the weight per stem (g) of three grasses of the Urochloa genus in growth curves. Independently of the grasses, the weight per stem decreases as the evaluation time passes. The highest weight per stem was obtained in the Piata grass at 56 days of regrowth with $1.8 \mathrm{~g}$, followed by Signal on day 49 with 1.7 and finally Piata on the same day with $1.6 \mathrm{~g}(\mathrm{P}>0.05)$. However, the lowest weight per stem was obtained by Signal grass with $0.1 \mathrm{~g}$ on day 7 after evaluation $(\mathrm{P}>0.05)$.

The weight per stem is closely related to the forage yield since as the weight per stem increases, the weight of a tiller and therefore a meadow increases [23]. In this regard, the age of the plant is a factor that determines an increase in weight per stem and senescent material and decreases leaf formation [15]. On the other hand, when evaluating Cuba 22 grass in the dry tropics, they reported the same trend and higher weights per stem than those of this investigation; however, they evaluated a species with higher height, yield, therefore, the weight per stem was higher [27].

\section{Conclusion}

As the regrowth age increased, the population dynamics of stems and weight per stem increased; in Insurgent and Signal the leaf elongation and net growth increased to a maximum point to start to decline; however, in Piata grass was increasing without decreasing. The trend of the leaf:stem relation was decreasing as the test progressed and senescence increased from day 21 of regrowth. Longer evaluation time is recommended and at different times of the year to expand the 
panorama of decisions in these structural characteristics of the meadow in the tropic.

\section{Conflicts of Interest}

The authors declare no conflicts of interest regarding the publication of this paper.

\section{References}

[1] Coppock, D.L. (1993) Grass Hay and Acacia Fruits: A Local Feeding System for Improved Calf Performance in Semi-Arid Ethiopia. Tropical Animal Health and Production, 25, 41-49. https://link.springer.com/article/10.1007\%2FBF02236885 https://doi.org/10.1007/BF02236885

[2] Quiroz-Cardoso, F.S., Rojas-Hernández, J., Olivarez-Pérez, E., Hernández-Castro, R., Jiménez-Guillén, A., Córdova-Izquierdo, A., Villa-Mancera and Abdel-Fattah, S. (2015) Composición nutrional, consumo e índice de palatabilidad relativa de los frutos de tres acacias en la alimentación de ovejas y cabras. Archivos de Medicina Veterinaria, 47, 33-38. https://scielo.conicyt.cl/pdf/amv/v47n1/art07.pdf https://doi.org/10.4067/S0301-732X2015000100007

[3] Bellon. M.R., Dulloo, E., Sardos, J., Thormann, I. and Burdon, J.J. (2017) In Situ Conservation-Harnessing Natural and Human-Derived Evolutionary Forces to Ensure Future Crop Adaptation. Evolutionary Applications, 10, 965-977.

https://www.ncbi.nlm.nih.gov/pubmed/29151853 https://doi.org/10.1111/eva.12521

[4] Dempewolf, H., Baute, G., Anderson, J., Kilian, B., Smith, C. and Guarino, L. (2017) Past and Future Use of Wild Relatives in Crop Breeding. Crop Science, 57, 1070-1082. https://pdfs.semanticscholar.org/2445/8157c75cacfbe368bd5312887964ce0504eb.pdf

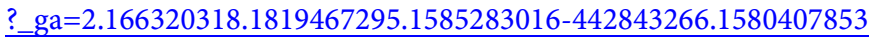
https://doi.org/10.2135/cropsci2016.10.0885

[5] Brummitt, N.A., Bachman, S.P., Griffiths-Lee, J., Lutz, M., Moat, J.F. and Farjon, A. (2015) Green Plants in the Red: A Baseline Global Assessment for the IUCN Sampled Red List Index for Plants. PLoS ONE, 10, 135-152. https://doi.org/10.1371/journal.pone.0135152

[6] Dempewolf, H., Eastwood, R.J., Guarino, L., Khoury, C.K., Müller, J.V. and Toll, J. (2014) Adapting Agriculture to Climate Change: A Global Initiative to Collect, Conserve, and Use Crop Wild Relatives. Agroecology and Sustainable Food Systems, 38, 369-377.

https://www.tandfonline.com/doi/full/10.1080/21683565.2013.870629

https://doi.org/10.1080/21683565.2013.870629

[7] Miller, R.E. and Khoury, C.K. (2018) The Gene Pool Concept Applied to Crop Wild Relatives: An Evolutionary Perspective. In: Greene, S.L., et al., Eds., North American Crop Wild Relatives, Vol. 1, Springer, Cham, 167-188.

https://cgspace.cgiar.org/bitstream/handle/10568/99185/Miller_genepool_2018_12_ 12.pdf? sequence $=3$ \&isAllowed $=\mathrm{y}$ https://doi.org/10.1007/978-3-319-95101-0_6

[8] Thornton, P. (2010) Livestock Production: Recent Trends, Future Prospects. Philosophical Transactions of the Royal Biological Sciences Society, 365, 2853-2867. https://www.ncbi.nlm.nih.gov/pmc/articles/PMC2935116/pdf/rstb20100134.pdf

[9] Brighenti, A.M., Sobrinho, F.S., Costa, T.R., Rocha, W.S.D., Martin, C.E. and Fer- 
reira, L.H.C. (2008) Integração Lavoura-Pecuária: A Cultura do Girassol Consorciada com Brachiaria Ruzizienses. Embrapa Gado de Leite, Juiz de Fora, MG (Embrapa Gado de Leite. Circular Técnica, 96), 1-12.

https://ainfo.cnptia.embrapa.br/digital/bitstream/item/65291/1/CT-96-Integracao-1 avoura-pecuaria.pdf

[10] Nguku, A.A., Musimba, N.K.R., Njarui, D.N. and Mwobobia, R.M. (2016) Thechemical Composition and Nutritive Value of Brachiaria Grass Cultivars at Katumancry Landre Search Station in South Eastern Kenya. Journal of Advances in Agriculture, 5, 706-717. https://doi.org/10.24297/jaa.v5i2.5085

[11] De Pinho Costa, K.A., Beneval, R., De Oliveira, I.P., Pettersen, C.D. and e Silva, E.D.C. (2005) Efeito da estacionalidade na produção de matéria seca e composição bromatológica da Brachiaria brizantha cv. Marandu. Ciência Animal Brasileira, 6, 187-193. https://www.revistas.ufg.br/vet/article/view/365/340

[12] Hernández, G.A., Martínez, H.P.A., Mena, U.M., Pérez, P.J. and Quiroz, J.F.E. (2002) Dinámica del rebrote en pasto Insurgente (Brachiaria brizantha Hochst. Stapf.) pastoreado a diferente asignación en la estación de lluvias. Técnica Pecuaria en México, 40, 193-205. https://www.redalyc.org/pdf/613/61340209.pdf

[13] Hernández-Garay, A., Matthew, C. and Hodgson, J. (1999) Tiller Size/Density Compensation in Perennial Ryegrass Miniatures Wards Subject to Differing Defoliation Heights and a Proposed Productivity Index. Grass and Forage Science, 54, 347-356. https://onlinelibrary.wiley.com/doi/abs/10.1046/j.1365-2494.1999.00187.x https://doi.org/10.1046/j.1365-2494.1999.00187.x

[14] Hirata, M. and Pakiding, W. (2004) Tiller Dynamics in Bahia Grass (Paspalum notatum): Ananalysis of Responses to Nitrogen Fertilizer Rate, Defoliation Intensity and Season. Tropical Grasslands, 38, 100-111.

http://tropicalgrasslands.info/public/journals/4/Historic/Tropical\%20Grasslands\%2 0Journal\%20archive/PDFs/Vol_38_2004/Vol_38_02_2004_pp100_111.pdf

[15] Cruz, H.A., Hernández, G.A., Enríquez, Q.J.F., Gómez, V.A., Ortega, J.E. and Maldonado, G.N.M. (2011) Producción de forraje y composición morfológica del pasto Mulato (Brachiaria híbrido 36061) sometido a diferentes regímenes de pastoreo. Revista Mexicana de Ciencias Pecuarias, 2, 429-443. http://www.scielo.org.mx/pdf/rmcp/v2n4/v2n4a7.pdf

[16] Rojas-García, A.R., Torres-Salado, N., Maldonado-Peralta, M.A., Sánchez-Santillán, P., García-Balbuena, A., Mendoza-Pedroza, S.I., Álvarez-Vázquez, P., Herrera-Pérez, J. and Hernández-Garay, A. (2018) Curva de crecimiento y calidad de pasto cobra (Brachiaria HIBRIDO BR02/1794) a dos intensidades de corte. Agroproductividad, 11, 24-28.

https://revista-agroproductividad.org/index.php/agroproductividad/\%20article/vie $\mathrm{w} / 368 / 256$

[17] Matthew, C., Hernández-Garay, A. and Hodgson, J. (1996) Making Sense of the Link between Tiller Density and Pasture Production. Proceedings of the New Zealand Grassland Association, 57, 83-87.

https://www.grassland.org.nz/publications/nzgrassland_publication_708.pdf https://doi.org/10.33584/jnzg.1995.57.2190

[18] Alves, M.G., De Pinho, C.K.A., Da Costa, S.E., Soares, E.P., Flávio, N.J., Gonçalves, R.M., Bezerra, F.P., Guimarães, S.J.F. and Gomes, G.W. (2014) Yield and Chemical Composition of Brachiaria Forage Grasses in the Offseason after Corn Harvest. American Journal of Plant Sciences, 5, 933-941.

https://file.scirp.org/pdf/AJPS_2014032610050581.pdf

https://doi.org/10.4236/ajps.2014.57106 
[19] Silva, M.L.O., Faria, M.A., Morais, A.R., Andrade, G.P. and Lima, E.M.C. (2007) Crescimento e Produtividade do Girassol Cultivado na Entressa fracom Diferentes Lâminas de Água. Revista Brasileira de Engenharia Agrícola e Ambiental, 11, 482-488. http://www.scielo.br/pdf/rbeaa/v11n5/v11n05a06.pdf https://doi.org/10.1590/S1415-43662007000500006

[20] García, E. (2004) Modificaciones al Sistema de Clasificación Climática de Koppen. 4th Editon, Universidad Nacional Autónoma de México, México, 217.

[21] Castro, R.R., Hernández-Garay, A., Ramírez, R.O., Aguilar, B.G., Enríquez, Q.J.F. and Mendoza, P.S.I. (2013) Crecimiento en longitud foliar y dinámica de población de tallos de cinco asociaciones de gramíneas y leguminosa bajo pastoreo. Revista Mexicana de Ciencias Pecuarias, 4, 201-215. http://www.scielo.org.mx/pdf/rmcp/v4n2/v4n2a6.pdf

[22] SAS (2011) The SAS 9.2 for Windows. SAS Institute Inc., Cary.

[23] Rojas, G.A.R., Ventura, R.J., Hernández, G.A., Joaquín, C.S., Maldonado, P.M.A. and Reyes, V.I. (2017) Dinámica poblacional de tallos de ovillo (Dactylis glomerata L.) solo y asociado con ballico perenne (Lolium perenne L.) y trébolblanco (Trifolium repens L.). Revista Mexicana de Ciencias Pecuarias, 49, 35-49. http://www.scielo.org.mx/pdf/rmcp/v8n4/2448-6698-rmcp-8-04-00419.pdf https://doi.org/10.22319/rmcp.v8i4.4646

[24] Rueda, J.A., Ortega, J.E., Enríquez-Quiroz, J.F., Palacios-Torres, R.E. and RamírezOrdoñes, S. (2018) Tiller Population Dynamics in Eight Cultivars of Elephant Grass during Undisturbed Growth. African Journal of Range \& Forage Science, 35, 1-11. https://doi.org/10.2989/10220119.2018.1477832

[25] Rodolfo, G.R., Schmitt, D., Dias, M.K. and Sbrissia, A.F. (2015) Levels of Defoliation and Regrowth Dynamics in Elephant Grass Swards. Ciência Rural, Santa Maria, 45, 1299-1304.

http://www.scielo.br/pdf/cr/v45n7/1678-4596-cr-0103_8478cr20141094.pdf https://doi.org/10.1590/0103-8478cr20141094

[26] Ramírez, R.O., Flores, I.A. Hernández, C.E., Rojas, G.A.R., Maldonado, P.M.Á. and Valenzuela, L.J.L. (2020) Dinámica poblacional de tallos e índice de estabilidad del pasto llanero (Andropogon gayanus Kunt). Revista Mexicana de Ciencias Agricolas, 24, 23-34. https://doi.org/10.29312/remexca.v0i24.2355

[27] Maldonado, P.M.A., Rojas, G.A.R., Sánchez, S.P., Bottini, L.M.B., Torres, S.N., Ventura, R.J., Joaquín, C.S. and Luna, G.M.J. (2019) Análisis de crecimiento del pasto Cuba OM-22 (Pennisetum purpureum x Pennisetum glaucum) en el trópico seco. Agroproductividad, 12, 17-22. https://doi.org/10.32854/agrop.v0i0.1445

[28] Wilson, G.C.Y., Zavaleta, M.H.A., López, D.H. and Hernández, G.A. (2008) La citoquinina BAP retrasa la senescencia, aumenta antioxidantes, proteína y crecimiento en el pasto ovillo (Dactylis glomerata L.). Agrociencia, 42, 799-806. https://www.redalyc.org/articulo.oa?id=30211207006

[29] Taiz, L. and Zeiger, E. (2002) Plant Physiology. 3rd Edition, Sinauer Associates, Inc., Massachusetts, 690.

[30] Ramírez, R.O., Hernández, G.A., Carneiro, D.C., Pérez, P.J., Enríquez, Q.J.F., Quero, C.A.R., Herrera, H.J.G. and Cervantes, N.A. (2009) Acumulación de forraje, crecimiento y características estructurales del pasto Mombaza (Panicum máximum Jacq.) cosechado a diferentes intervalos de corte. Técnica Pecuaria en México, 47, 203-213. https://www.redalyc.org/articulo.oa?id=61312116008 